brazilianpoliticalsciencereview

ARTICLE

\title{
The Stratification of Diversity: Measuring the Hierarchy of Brazilian Political Science*
}

\author{
Fernando Leite \\ Universidade Federal do Paraná, Brazil
}

\begin{abstract}
This article proposes an indicator for measuring the hierarchy of academic production in Brazilian political science, based on Qualis, the impact factor and the share of articles on Political Science in selected journals. The dataset comprises 23 renowned national journals. Findings show that disciplinary traditions emphasizing institutional analysis as well as quantitative and nomothetic approaches, based on the proposition and testing of hypotheses and causal arguments predominate. This state of affairs, in turn, is explained by particular parameters for evaluating the academic production, that is, the institutionalization of a specific disciplinary view, a scientificpolitological one.
\end{abstract}

Keywords: Brazilian political science; hierarchy of production; Qualis; disciplinary traditions; evaluation.

$\mathrm{V}$ igorous production about a discipline, particularly by its own initiative, is a sign of maturity. Recent literature on Brazilian political science shows the considerable degree of complexity and relative intellectual wealth achieved. Over the past 15 years, a myriad of areas, approaches and journals have arisen, ever more extensively since its conception as an autonomous discipline in the

(*) http://dx.doi.org/10.1590/1981-38212016000100006 For replicating data, see bpsr.org.br/files/archives/Dataset_Leite. 
late $1960 \mathrm{~s}^{1}$. The institutional development of the discipline run along this process, as shown by the growth of post-graduate courses and the establishment of objective criteria for evaluating academic institutions and research ${ }^{2}$. In this sense, the objectification of these criteria makes explicit certain stratification mechanisms that had previously remained more or less implicit, relying on subjective evaluation among peers. In other words, the growing maturity of the discipline allows for a clearer identification of the principles that, at the same time, differentiate and stratify it.

However, this measurement of the discipline - its hierarchy - has not yet been systematically addressed in the literature. Analyses of the history of the discipline focus on the trajectory of themes, approaches and groups of political and social scientists in the constitution of the discipline, some favoring endogenous factors of the academic field, such as Quirino (1994), Almeida (2001), Peixoto (2001) and Marenco (2015), and others favoring exogenous factors, such as Arruda (2001) and Miceli (1990, 1993), as well as hybrid approaches such as Lamounier (1982), Trindade $(2007,2012)$ and Forjaz (1997). They answer to questions such as what are the theoretical and methodological influences of the discipline, what were the main groups that contributed to its formation, in which university environment they were formed and what political context influenced them. In all cases, the hierarchy of the discipline is more or less implicit in the transformations described and in the themes and approaches highlighted, but it is not explored. Analyses of the 'field' so far undertaken, such as Lessa $(2010,2011)$, tend to highlight its diversity, without addressing its hierarchy. The few analyses that aim to rebuild systems of opposition, such as Keinert and Silva (2010), consider exogenous factors in determining the oppositions among groups, without analyzing the structure of production. Finally, meta disciplinary studies have evaluated the quality of production (REIS, 1997; SOARES, 2005), but little attention was paid to the parameters from which the quality is evaluated, assessing the discipline from $a$ specific disciplinary view, using a specific property as a criterion for defining political science.

This paper proposes an indicator to identify and measure the hierarchy of production. It shows the hierarchy of relevant categories of production in contemporary Brazilian political science analyzing its field of production, addressing several disciplinary views.

\footnotetext{
${ }^{1}$ For an overview of the evolution of theoretical and methodological guidelines since the 1970s, see Oliveira and Nicolau (2014). For an overview of the fields, see Martins and Lessa (2010).

2 Marenco (2015) measures the institutional development of the discipline analyzing the evolution of post-graduate courses, the number of PhDs, the ratio of thesis and dissertations, the thematic structure of the courses, among others, as well as evaluating the quality of the production of the courses against criteria such as the number of courses with grade 07 in Capes, and level A1 production per capita in QUALIS, among others.
} 
Like other fields, certain attributes in the academy are valued more or less than others. These attributes are identified in products, such as books, articles, and papers, which are thus judged by the presence or absence of given qualities. Likewise, since certain attributes are more valued than others, certain judgments acquire more prominence in the field. In Brazilian political science, this occurred through production evaluation systems such as Qualis ${ }^{3}$, and measures of the 'impact' of the publications such as the Impact Factor (IF). Through these mechanisms, certain attributes were institutionalized, acquiring power over the production and eventually imposing themselves on the others. They were thus transformed into objective parameters of quality measurement. What are these attributes? What is the hierarchy derived therefrom? This paper aims to answer these questions.

The article is organized as follows. The first section presents the context in which the indicator was applied. It also presents and briefly describes the categories used as references to identify the hierarchy, i.e. the foundations of academic production. The second section presents the indicator, revealing its assumptions and parameters, and the hierarchy of the renowned journals. The third section details the hierarchy of academic production and identifies the disciplinary views that influence the hierarchy of the field.

\section{Methodology}

The indicator can be used to calculate the value of any production category, as long as subjected to the same mechanisms of stratification. In this research, we evaluate some of the most relevant categories in the production of contemporary Brazilian political science: areas, approaches, disciplinary traditions and intellectual traditions.

The field of production analyzed is comprised of 23 renowned national journals listed by Qualis. The last classification available at the time of writing was used as a reference, published in 2013. The analysis spans the three-year period of 2010-2012, corresponding to the last triennial of the Coordination of Higher Education Personnel Training (CAPES) evaluation of graduate programs, making for a universe of 567 articles.

As most of the journals are interdisciplinary, not all articles were analyzed. Without resorting to an arbitrary definition of political science, the filtering adhered to the following criteria: 1) institutional link: to be linked to a graduate program in the political science field, according to CAPES; 2) subjective identification: to include political science as an area of

\footnotetext{
${ }^{3}$ CAPES is the federal agency responsible for setting the rules for evaluating graduate programs. The important part of the evaluation refers to the quantity and quality of the publications. The quality of the publications is measured using a journal assessment system, called the Qualis System.
}

(2016) $10(1) \quad$ - $00006-3 / 29$ 
expertise in the Lattes national CV database; 3) participation in the Brazilian Political Science Association Meeting; 4) participation on a doctoral board in political science. The reference is the first author of the article. To be included, the article had to comply with at least one of these conditions. Literature reviews, introductions, presentations, summaries, opinions, interviews, tributes, critiques, and the like were not considered (LEITE, 2015, p. 06).

The criteria of selection are based on the influence exerted on the field of production through institutionalized means. They allow us to comprise topics of border zones, involving more unorthodox forms of political science - which, nevertheless, are objectively part of the field and have symbolic efficacy over it. The political scientists themselves mark the borders: either by subjective identification or institutional affiliation or by legitimacy granted to the author, to disseminate ideas or exert power over the production field upon accepting it the BPSA Meeting or on doctoral boards. These parameters make up the following universe (Table 01):

Table 01. Journals examined

\begin{tabular}{|c|c|c|c|c|c|}
\hline Journals & Volumes & Issues & $\begin{array}{c}\text { Total } \\
\text { (articles) }\end{array}$ & $\begin{array}{l}\text { Articles } \\
\text { Selected }\end{array}$ & $\begin{array}{c}\% \text { of PS } \\
\text { articles in } \\
\text { the journal }\end{array}$ \\
\hline Dados & 03 & 06 & 83 & 45 & 54,2 \\
\hline $\begin{array}{l}\text { Revista Brasileira de Ciências } \\
\text { Sociais }\end{array}$ & - & 09 & 85 & 29 & 34,1 \\
\hline Opinião Pública & 03 & 06 & 59 & 59 & 100 \\
\hline Brazilian Political Science Review & 03 & 06 & 30 & 26 & 86,6 \\
\hline Revista de Sociologia e Política & 03 & 10 & 124 & 86 & 69,3 \\
\hline Lua Nova & - & 09 & 66 & 31 & 59,1 \\
\hline Revista de Economia Política & 03 & 12 & 128 & 10 & 7,8 \\
\hline Novos Estudos & - & 09 & 78 & 25 & 32 \\
\hline $\begin{array}{l}\text { Revista Brasileira de } \text { Ciência } \\
\text { Política }\end{array}$ & - & 08 & 81 & 74 & 91,3 \\
\hline Caderno CRH & 03 & 11 & 124 & 27 & 21,7 \\
\hline Cadernos de Pesquisa & 03 & 08 & 109 & 14 & 12,8 \\
\hline Cadernos Pagu & - & 06 & 72 & 03 & 4,1 \\
\hline Ciência e Saúde Coletiva & 03 & 33 & 782 & 52 & 6,6 \\
\hline Estudos Históricos & 03 & 06 & 53 & 13 & 24,5 \\
\hline História (São Paulo) & 03 & 06 & 102 & 07 & 6,8 \\
\hline Religião e Sociedade & 03 & 06 & 56 & 09 & 16 \\
\hline Revista Estudos Feministas & 03 & 09 & 127 & 16 & 12,6 \\
\hline Saúde e Sociedade & 03 & 15 & 270 & 03 & 1,1 \\
\hline Sociedade e Estado & 03 & 09 & 79 & 14 & 17,7 \\
\hline Sociologias & 03 & 08 & 72 & 12 & 16,6 \\
\hline Estudos Avançados & 03 & 09 & 199 & 03 & 1,5 \\
\hline Tempo Social & 03 & 06 & 65 & 01 & 1,5 \\
\hline Ambiente e Sociedade & 03 & 06 & 75 & 08 & 10,6 \\
\hline Total & & & 2919 & 567 & 19,4 \\
\hline
\end{tabular}

Note: The remaining four articles refer to International Relations. 
The content of the articles was analyzed with categorical variables: journals, approaches, thematic areas, disciplinary and intellectual traditions, as well as criteria for 'scientificity'. With the exception of the journals, the categories proposed are original. We chose them because they describe effective properties of the intellectual structure. They are 'effective' in the sense that, in addition to characterizing the production, they are also responsible for organizing the structure of the field: political science is largely conducted as a result of these properties, with much of its variance structuring the space of oppositions (LEITE, 2015). Furthermore, the categories have a specific worth, assigning a hierarchy to the structure. The unequal valuation of its properties means the field is unequal as well as differentiated.

\section{Thematic areas}

What form do these properties take? In addition to the journals, a self-evident category, are the thematic areas. Areas are more or less institutionalized sets of related research objects. They are the leading factor in the organization of production: they define the margin of objects subject to study, conditioning the possible set of phenomena to be studied. The structure of areas thus represents a range of more or less legitimate objects - the most legitimate, in general, being the most valuable and/or the most traditional. It is basically the discipline's answer to the questions 'what to study' and 'what should be studied' - largely defining the identity of the discipline. The list of areas was prepared based on the CAPES/CNPq 'Areas of Expertise'4 and the BPSA 'Thematic Areas' (TAs) ${ }^{5}$, which were compared and adjusted to the contents of the publications analyzed.

\section{Approaches}

Approaches are less institutionalized than thematic areas but are also important in the characterization of production and definition of the discipline. An approach refers to 1 ) a set of ideas regarding an object, 2) the procedures used to study it and 3) the attributes, factors or variables that the analyst assumes, deduces or infers by studying

\footnotetext{
4'Areas of Expertise Table', CAPES, 2012. Available at http://www.capes.gov.br/avaliacao/instrumentos-de-apoio/tabela-de-areas-do-conhecimentoavaliacao. Accessed on May 30, 2014.

5 'Thematic areas', BPSA, 2012. Available at http://www.cienciapolitica.org.br/encontros/8oencontro-abcp/areas-tematicas/. Accessed on May 30, 2013.
} 
the object. Approaches are frequently brought to consciousness and classified, often in isms, identifying positions in the intellectual structure of the field. A culturalist approach, for example, can study the political culture of a nation or a specific group, the behavior of voters or of elected politicians, the political opinions of civil groups, media phenomena, etc. Affinities between the definition and the approach to the object create patterns, allowing the abstraction of recurring properties and thus the formulation of nominal approaches: 'neo-institutionalism', 'Marxism', 'pluralism', and so on. The nominal approaches were rebuilt from Leite's criteria (LEITE, 2015, pp. 155-160), from manuals, studies on the history of the field and substantive references.

Of course, a theoretical and methodological approach goes beyond the nominal approach in which it is classified. Nominal approaches are constructs that specify sets of objects, concepts, and methods that are more or less cohesive, relatively persistent and with a minimum degree of legitimacy. They are abstractions analogous to the theoretical construction of the 'working class' or 'intellectual class'; they are theoretical classes anchored in the intellectual history of the field. Thus, nominal approaches are important but are not the only way to specify the approach of a study, with other categories to be considered, such as the nature of the object, the nature of the evidence, use of statistics, etc.

But although an approach is clearly defined, it is a difficult construct to operationalize: there are approaches of low formal expression - unlike Marxism, for example, which classifies research centers, journals, and people. Since the existence of approaches is out of question, the problem is how to grant an empirical basis to constructs of informal facts with a variable degree of institutionalisation. The problem is similar to one faced by contemporary political science, the study of informal institutions, that is, institutions of socio-cognitive nature. In this sense, the institutionalization and cohesion of each approach vary greatly within the list and we do not distinguish these differences. There is consensus on the existence of a handful of new institutionalisms, but less regarding the distinction between behaviorism and informational - a decision of our own. Another problem is the degree of extension of each approach: some encompass theories and methods (i.e., hermeneutics), others partly overlap with a theory (rational choice), while others focus on methodological procedures (content analysis).

The second question is: are the approaches important in the hierarchy of the field? We believe they are fundamental, because thematic areas define objects, but are 
the approaches that specify the means by which the objects are examined. Both constitute the backbone of academic production and the intellectual structure of the field, the former being more formal, and the latter more informal. Keeping in mind that no study has systematically rebuilt the approaches of the field - neither in the United States nor elsewhere - it is essential to propose criteria and a list, to highlight their shortcomings and to encourage revisions and improvements. Without approaches, we would lose sight of an entire dimension of the field, like a political science that would reduce politics to its formal expression.

\section{Disciplinary and intellectual traditions}

Disciplinary and intellectual traditions are important principles of division in the field: among other factors, production is distinguished and organized according to traditions. A tradition is a more or less coherent set of historically persistent ideas and thinking habits. It is a mindset that provides general parameters of interpretation ${ }^{6}$. Traditions are manifested at various levels in the academic field, and guide intellectual categories (such as approaches) and organizational categories (knowledge produced in universities, societies or scholarly circles; the means of publishing, such as articles or books; the organization of libraries, the classification of sciences, typographic standards etc.) (BURKE, 2000).

Disciplinary traditions are particular to political science. Considering the history of Brazilian political science, we identified the following traditions: politological, intermediate and politicist; state and statist; societal and societalist; economic and economist; and idealist. Politological means taking institutional politics ${ }^{7}$ as the scope of the object. Politicism takes institutional politics as the scope and treats it as a fully autonomous order, determined strictly by internal factors. Objects immediately overlaying institutional politics and directly articulated to it, such as the behavior of voters, the subjective evaluation of political institutions and the institutionalized

\footnotetext{
${ }^{6}$ Notice that a tradition should not be confused with a school, such as the 'São Paulo sociological school' or the 'school of Michigan', distinguished by 1) being more located in time, 2) being more located in the intellectual or scientific field, and 3) the necessary involvement of discipleship. ${ }^{7}$ Arrangement of organizations responsible for the legitimate exercise of political power (power over other forms of power) - including informal institutions in place within that arrangement. It is marked by competition for the possession of government positions and for the control of resources under government tutelage, as well as the decisions on their application in the form of public policy. It includes the vote and institutionalized forms of participation. For further details, see Leite (2015, pp. 144-150).
} 
participation of civic actors, are encoded as an intermediary politological type. Statal studies an object within the state, minus institutional politics and statism treats it as a purely autonomous order. Societal studies an object of societal scope, including power, inequalities and forms of domination, mobilizing factors of diverse scopes. Societalism treats institutional politics as dependent on societal factors ${ }^{8}$. Similarly, economic studies an object of economic (such as economic growth) or political-economic scope (such as development politics) and economistic treats institutional politics as dependent on economic factors. Idealism, in turn, studies linguistic-ideal objects or treats them as determinants of an object pertaining to some of the other scopes.

Among the intellectual traditions, there are oppositions related to the scope and models of intellectual activity. Scope and breadth of the argument refer to classical oppositions of the social sciences that we found apply to political science. The scope evaluates to which side the argument is closer, within the nomothetic and idiographic continuum. The more nomothetic, the more the inferences are inclined to generalization; the more idiographic, the more the conclusions are inclined to specifics. The breadth verifies to which side the argument is closer: agency/subjectivism or structure/objectivism. The higher the collective character, the broader and more systemic the terms used to describe the object, the more structural it is; conversely, the more dependent on the action of individuals, groups or organizations, the closer it is to agency.

Oppositions between models of intellectual activity, scientific or humanistic, are also reproduced in political science. The main cognitive faculty of the humanistic model is understanding and interpretation, and it asks the fundamental question, what's the meaning (KAPLAN, 1964, p. 33). Historically, it is based on the curricular structure of the studia humanitatis, which reformed European universities between the fifteenth and sixteenth centuries, incorporating Philosophy afterward. This model is present today in the "Philosophy, Letters and Arts" university system (BURKE, 2000, pp. 18-22, pp. 81115). The so-called 'essayism' is part of the humanistic model. The scientific model's

8 It is important to note this difference to societal tradition: societalism takes institutional politics as an object. In addition, Lamounier (1982, p. 417) uses the term 'sociologism' in a sense similar to that which here is specified by the term 'societal' - but there is reference to sociological approaches, to a sociological treatment of societal objects, while 'societal' refers exclusively to the object, involving approaches that are not necessarily sociological - some political theory approaches, for example, are largely societal (although sociology echoes in the background, such as Habermas's deliberationalism). 
main faculty is explanation; it tends to ask what is and why. It is distinguished from the humanistic model by its fundamental interest in the proof of specific propositions. Historically it is linked to the autonomization of 'Natural Philosophy' of the eighteenth century and the rise of epistemic empiricism, which lays down the epistemological foundations of the natural sciences (idem). It is in this context that the distinction arises between 'qualitative' and 'quantitative knowledge' by Galileo, from which the scientific model, focused on physics, adopts mathematics (BURKE, 2000, pp. 85-86).

In the context of the social sciences, the scientific model is often called 'positivism', expressing a conflict between conceptions of science. In this study this conflict is measured by measures of scientificity, defined by an orthodox, 'positivist' framework. Thus, the more a certain category scores on these attributes, the closer it is to the scientific model; the less, the closer it is to the humanistic model. The following variables are used: nature of the object, nature of the evidence, usage of statistics, presentation and testing of hypotheses, and causality.

The nature of the object can be empirical, theoretical, or linguistic-ideal. In the first case, the object is directly or indirectly observable or refers to a construct (like the terms 'state' or 'culture') submitted to measurement of any kind. A theoretical object is an abstract term that refers to a theoretical system. A linguistic-ideal object is a linguistic construction or a mental fact, such as an idea, text or thought that does not constitute a theoretical term.

The nature of the evidence may be quantitative, qualitative, hybrid (quantitative and qualitative) or bibliographic. The first three make empirical evidence. The bibliographical evidence is typical of essays and theoretical studies: the object is approached with reference to third-party ideas, accessed by written record.

The following types of statistics are discerned: simple frequency, univariate, bivariate, and GLM. Simple frequency and univariate statistics involve summary statistics, such as measures of central tendency (mean, median), dispersion (quartiles, percentiles), variability (variance, standard deviation, boxplot), and morphological analyzes (such as skewness, kurtosis, and histograms). Bivariate statistics is composed of measurements of interaction between two variables ${ }^{9}$. GLM refers to General Linear Model, the linear model that underlies most statistical functions, such as regression

\footnotetext{
${ }^{9}$ These tests may or may not be inferential, i.e. generalizations from a sample.
} 
analysis, analysis of variance and covariance (ANOVA and ANCOVA), among others. No studies with multivariate techniques, Bayesian analysis or others were identified.

Finally, we checked whether the studies envisaged a causal explanation by means of the test of hypothesis. The scientific model favors empirical objects, quantitative evidence, use of statistics, presentation and testing of hypotheses, and causal arguments, in addition to a nomothetic scope. The humanistic model involves empirical and theoretical objects, correlates more with linguistic-ideal, favors and qualitative and bibliographic evidence, works less with hypothesis and causal arguments, and favors an idiographic scope.

The coding procedure was as follows: we read the abstract, keywords, introduction, and conclusion. We read the introduction and the conclusion in search of categories not identified in the title, abstract or keywords. For example, to check whether a study had a nomothetic orientation, we sought for inferences on the conclusions. If in doubt, we resorted to the body of the text. This was necessary, in particular, to identify the nominal approach, guided by the bibliography of references and the keywords (such as 'rules' and neo-institutionalism, 'ideology' and Marxism, 'recruitment' and analysis of elites, etc ${ }^{10}$ ). In addition, we searched the text for any data that necessarily belongs in that region, such as the nature of the evidence. In general, the encoding of each article took 10 to 20 minutes. The data was processed by the IBM SPSS statistical package, version 21 .

\section{Indicator}

Qualis is currently the most effective stratification mechanism in the field. It is part of a graduate evaluation system, administered by CAPES. The important part of the evaluation refers to the quantity and quality of the publications. The quality is measured using a journal assessment system, called the Qualis System, in which each area of expertise categorizes national and international journals into the following strata: A1, A2, B1, B2, B3, B4, B5, and C. For some time, the so-called 'qualified production', the strata effectively considered to measure academic performance of graduate fellows in political science, has been defined as publication in A1, A2 and B1 journals ${ }^{11}$.

10 The list of references can be found in Leite (2015, p. 157).

${ }^{11}$ For an analysis of Qualis and its effectiveness in the stratification of the field of production, cf. Leite and Codato (2013) and Marenco (2015). For a critique of Qualis, cf. Rocha and Silva (2009). 
The impact factor (IF), in turn, is a more subtle mechanism for assigning value based on the ratio between citations made and received. The more the article is cited, the more it is assumed to impact on production - i.e., the more it influences the structure of the field 12 . Scientific recognition is associated with citations.

With the stratification mechanisms in hand, the value assigned to the journals can be calculated, and through it, the value assigned to the categories of production. This involves the postulate of transfer of capital between cultural products and their means of distribution (BOURDIEU, 1984, pp. 125-168). Here, the products are the articles, the categories are the intellectual properties and the means of diffusion are the journals. The journals transfer to the articles the value previously assigned to them by the stratification mechanisms. The hierarchy/value of the articles, therefore, depends on the hierarchy/value of the journals. In field analysis, these categories act as properties, i.e. attributes that structure the field.

How is the value of a category calculated? Qualis and the impact factor can be interpreted as measurements of 'density', i.e. the amount of value invested in each unit of the category in a given period. In other words, journals are coefficients of value. These coefficients represent the 'weight' of the journals.

There is an important detail. Much of the output of Brazilian political science is still produced through interdisciplinary journals, some quite eclectic, such as Ciência e Saúde Coletiva, and others linked to other disciplines, such as História. This strongly affects the impact factor. Ciência e Saúde Coletiva, for example, has a much higher impact factor than Opinião Pública (0.519 compared to 0.350) - but this value is largely associated to other disciplines while Opinião Pública is a journal of political science. Thus, if we do not discern the strength of the link to the discipline, the calculated value will be distorted by evaluation related to other fields. The impact factor must be considered in proportion to the contingent of studies related to political science.

The journal's value coefficient is, therefore, the sum between Qualis and the average of the impact factor and the proportion of political science articles in the journal (Table 02).

The coefficient is then multiplied by the number of cases that the category occupies in the journal (the volume). This procedure is repeated for all journals in which the category appears. The sum gives us the gross measure of value $\left(\mathrm{V}_{\mathrm{g}}\right)$, the volume of capital concentrated

${ }^{12}$ According to Thomaz, Assad and Moreira (2011, p. 91): "To calculate the IF of a given year, the number of citations received in that year by articles published by the journal in the previous two years is taken into consideration, then divided by the number of articles published by the journal in the same period". 
by the category. Hypothetically, the greatest gross value that a category could have is 949.725 - a figure that corresponds to the concentration of all production (567 articles) in the most valuable journal. The smallest possible value is 0.755 , representing one occurrence in the least valuable journal.

In addition to the gross value, another important measure of the hierarchy of production is the relative value $\left(\mathrm{V}_{\mathrm{r}}\right)$. The relative value measures how much value is concentrated in each case of a category. It is calculated by dividing the overall value of the category by its number of occurrences in the production. In other words, it is a per capita value, a measure of yield.

The magnitudes of these measures are as follows: (i) the maximum relative value that a category can have equals the value coefficient of the most valuable journal (Opinião Pública, 1.675). In this case, the category would be entirely concentrated in this journal. Conversely, the minimum corresponds to the coefficient of the least valuable journal (Estudos Avançados, 0.755).

Table 02. Production raking formula

\begin{tabular}{|c|c|}
\hline $\begin{array}{l}\text { Gross Value of the } \\
\text { Category }\left[\mathrm{V}_{\mathrm{g}}\right]\end{array}$ & $\begin{array}{l}=\text { Sum of specific category values }\left[\mathrm{V}_{\mathrm{e}}\right] \text { in all observed journals: } \mathrm{Vg}= \\
\sum \mathrm{Ve}\end{array}$ \\
\hline $\begin{array}{l}\text { Specific Category } \\
\text { Value }\left[\mathrm{V}_{\mathrm{e}}\right]\end{array}$ & $=\mathrm{N}$ of cases in the Journal [n] $\mathrm{x}$ Journal Coefficient Value $[\mathrm{C}]: \mathrm{Ve}=\mathrm{n} . \mathrm{C}$ \\
\hline $\begin{array}{l}\text { Journal Coefficient } \\
\text { Value [C] }\end{array}$ & $\begin{array}{l}\text { = Sum of the Journal's Qualis value }[\mathrm{Q}] \text { and the arithmetic mean of its } \\
\text { impact factor }[\mathrm{Fi}] \text { and the share of } \mathrm{PC} \text { articles in the Journal: } \\
\qquad \mathrm{C}=\mathrm{Q}+\left(\frac{\mathrm{Fi}+\mathrm{CP}}{2}\right)\end{array}$ \\
\hline $\begin{array}{l}\text { Relative Value of the } \\
\text { Category }\left[\mathrm{V}_{\mathrm{r}}\right]\end{array}$ & $\begin{array}{l}=\text { Ratio of the gross value/share of the category and the total number of } \\
\text { cases in the production: } \frac{\mathrm{Vc}}{n} \text {; standardized at: } \mathrm{Zi}=\frac{\mathrm{Xi}-\min (\mathbf{x})}{\max (\mathbf{x})-\min (\mathbf{x})}\end{array}$ \\
\hline \multirow{3}{*}{ Parameters } & $\mathrm{Q}: \mathrm{A} 1=1|\mathrm{~A} 2=0,85| \mathrm{B} 1=0,70$ \\
\hline & SciELO (Scientific Electronic Library Online): 2011-2012* \\
\hline & nal and Country Ranking): 2005-2012 \\
\hline
\end{tabular}

Note: Impact factor for a two-years' period; 2013 is the baseline, except for the Brazilian Political Science Review, whose baseline year is 2014. 
The $V_{r}$ was then normalized using the min-max method, ranging from 0.000 to 1.000. For its interpretation, five strata were adopted: 'very low' $=0.000$ to 0.200 ; 'low' $=0.201$ to 0.400 ; 'average' $=0.401$ to 0.600 ; 'high' $=0.601$ to 0.800 ; 'very high' $=0.801$ to 1.000. Its standardization is based on the concept of 'qualified production', that is, the cut-off line established by the area committee of political science in CAPES, which determines when the journal is deemed to have value in the classification of graduate programs. Therefore, due to the dominant stratification criteria, values below 0.755 are negligible, constituting the minimum value in the standardized scale.

The indicator is summarized in Table 03 below:

Table 03. Journals Coeficient Values

\begin{tabular}{lccccc}
\hline Journals & Strata & $\mathrm{Q}$ & $\mathrm{Fi}$ & $\mathrm{CP}$ & $\mathrm{C}_{\mathrm{v}}$ \\
\hline Opinião Pública & $\mathrm{A} 1$ & 01 & 0,350 & 01 & 1,675 \\
Dados & $\mathrm{A} 1$ & 01 & 0,363 & 0,542 & 1,453 \\
Revista Brasileira de Ciências Sociais & $\mathrm{A} 1$ & 01 & 0,356 & 0,341 & 1,348 \\
Brazilian Political Science Review & $\mathrm{A} 2$ & 0,85 & 0,095 & 0,866 & 1,330 \\
Lua Nova & $\mathrm{A} 2$ & 0,85 & 0,318 & 0,591 & 1,304 \\
Revista de Sociologia e Política & $\mathrm{A} 2$ & 0,85 & 0,187 & 0,693 & 1,290 \\
Revista Brasileira de Ciência Política & $\mathrm{B} 1$ & 0,70 & 0,207 & 0,913 & 1,260 \\
Ciência e Saúde Coletiva & $\mathrm{B} 1$ & 0,70 & 0,519 & 0,066 & 0,992 \\
Novos Estudos & $\mathrm{B} 1$ & 0,70 & 0,261 & 0,320 & 0,990 \\
Revista de Economia Política & $\mathrm{A} 2$ & 0,85 & 0,177 & 0,078 & 0,977 \\
Caderno CRH & $\mathrm{B} 1$ & 0,70 & 0,150 & 0,217 & 0,884 \\
Sociedade e Estado & $\mathrm{B} 1$ & 0,70 & 0,187 & 0,177 & 0,882 \\
Estudos Históricos & $\mathrm{B} 1$ & 0,70 & $0,114 *$ & 0,245 & 0,879 \\
Cadernos de Pesquisa & $\mathrm{B} 1$ & 0,70 & 0,2250 & 0,128 & 0,876 \\
Religião e Sociedade & $\mathrm{B} 1$ & 0,70 & 0,1875 & 0,160 & 0,873 \\
Saúde e Sociedade & $\mathrm{B} 1$ & 0,70 & 0,3284 & 0,011 & 0,869 \\
Revista Estudos Femininos & $\mathrm{B} 1$ & 0,70 & 0,2069 & 0,126 & 0,866 \\
Sociologias & $\mathrm{B} 1$ & 0,70 & 0,1667 & 0,166 & 0,866 \\
Ambiente e Sociedade & $\mathrm{B} 1$ & 0,70 & 0,2037 & 0,106 & 0,854 \\
Cadernos Pagu & $\mathrm{B} 1$ & 0,70 & 0,1837 & 0,041 & 0,812 \\
Revista de História & $\mathrm{B} 1$ & 0,70 & $0,101^{* *}$ & 0,068 & 0,784 \\
Tempo Social & $\mathrm{B} 1$ & 0,70 & 0,1064 & 0,015 & 0,761 \\
Estudos Avançados & $\mathrm{B} 1$ & 0,70 & 0,0947 & 0,015 & 0,755 \\
\hline Sources: Scielo and Scopus & & & & &
\end{tabular}

Sources: Scielo and Scopus

Notes: $\left({ }^{*}\right)$ The impact factor of Estudos Históricos was not available at SciELO. We adopted the mean of the SJR values for 2000 to 2005.

$\left.{ }^{* *}\right)$ Not available at SciELO. Adopted SJR value for 2012.

The parameters are adjusted to the particular context of analysis, assuming the values for the period considered. The source chosen for calculating the impact factor 
was the SciELO, with the latest values available (2011-2012). The SJR ${ }^{13}$ was not used because several journals were not indexed by SCImago ${ }^{14}$. The values assigned to the Qualis strata are those used by the Committee for the Field of Political Science and International Relations in the evaluation of graduate programs.

It should be noted that there is some room for redundancy in the formula, as the impact factor is considered to distinguish A1 and A2 journals in the Qualis (CAPES, 2013, p. 25). However, the redundancy is insignificant, as the criterion is 'SJR greater than 0.30 ' for $A 1$ and, for A2, simply to be indexed by the SJR or JCR ${ }^{15}$. Under these circumstances, to assume that the impact factor is covered by the Qualis is to relinquish a ratio scale for an ordinal scale - and fairly generic one consisted of 'more' or 'less than $x^{\prime}$. The impact factor must be fully considered since it covers a dimension of capital barely done by Qualis. With the coefficient in hand, the formula may be applied to any category in order to determine its specific hierarchy.

We remind that only categories relevant to the structure of the field are significant as measures of its hierarchy. This can be verified with dimension reduction techniques such as correspondence analysis: if the category contributes significantly to a dimension of the field, so will its specific hierarchy (LEITE, 2015). Finally, the distribution of academic capital in the production must be interpreted taking into account both the gross value $\left(V_{g}\right)$ and the relative value $\left(V_{r}\right)$.

\section{Hierarchy of production}

\section{Thematic areas}

The areas were aggregated into classes, taking the organization of the thematic areas of the 2013 BPSA Annual Meeting as a reference. The results are as follows (Table 04):

13 Part of the SCImago Journal \& Country Rank, the purpose of the SJR is to demonstrate the 'visibility' of the journals indexed in the Scopus database, owned by Elsevier, and it is used as one of the key indicators of the impact of publications. It is generally interpreted as a quality indicator, but may also be interpreted as an indicator of scientific prestige.

${ }^{14}$ For journals with available data, the SJR (2005-2012) did not substantially alter the results - in fact, the gap between the most and least valued journals actually increased.

15 Journal Citation Reports, citation indicators calculated from the Web of Science (WOS) database, owned by Thomson Reuters. It is JRS's main competitor. According to Setenareski (2013, p. 35), in 2013, a partnership was signed between SciELO and Thomson Reuters, which from 2014 will calculate the Impact Factor of their journals. 
Table 04. Ranking of thematic areas

\begin{tabular}{|c|c|c|c|c|c|}
\hline Thematic Area & $\mathrm{N}$ & $V_{g}$ & Position & $\mathrm{V}_{\mathrm{r}}$ & Position \\
\hline \multicolumn{6}{|c|}{ Communication, representation and political behavior } \\
\hline $\begin{array}{l}\text { Electoral studies and political } \\
\text { Parties }\end{array}$ & 40 & 55,837 & $02^{\underline{o}}$ & 0,697 & $04^{\circ}$ \\
\hline Political culture and attitudes & 30 & 40,939 & $05^{0}$ & 0,663 & $06^{0}$ \\
\hline $\begin{array}{l}\text { Political communication and public } \\
\text { Opinion }\end{array}$ & 20 & 26,860 & $08^{\circ}$ & 0,639 & $07^{\circ} \stackrel{0}{2}$ \\
\hline Participation institutions & 16 & 19,733 & $13^{\circ}$ & 0,520 & $14^{\circ}$ \\
\hline \multicolumn{6}{|c|}{ Political institutions } \\
\hline Legislative studies & 08 & 10,743 & $22^{\circ}$ & 0,639 & $08^{\circ}$ \\
\hline Executive-legislative relations & 08 & 11,648 & $20^{\circ}$ & 0,762 & $01^{\circ}$ \\
\hline Intergovernmental relations & 05 & 6,053 & $26^{\circ}$ & 0,495 & $16^{\circ}$ \\
\hline Electoral and party systems & 16 & 22,225 & $12^{\mathrm{o}}$ & 0,689 & $04^{\circ}$ \\
\hline Governamental systems & 09 & 11,888 & 19 o & 0,615 & 09 은 \\
\hline Decision-making process & 07 & 10,137 & $23^{\circ}$ & 0,753 & $02^{\circ}$ \\
\hline $\begin{array}{l}\text { Government, bureaucracy, and } \\
\text { public policy }\end{array}$ & 122 & 125,684 & $01^{\text {음 }}$ & 0,299 & $25^{\circ}$ \\
\hline Local-level studies & 07 & 8,751 & $24 \underline{0}$ & 0,538 & $13^{\circ}$ \\
\hline \multicolumn{6}{|c|}{ State and civil society } \\
\hline $\begin{array}{l}\text { Structure and transformation of the } \\
\text { state }\end{array}$ & 24 & 28,169 & $7^{0}$ & 0,455 & $19^{\circ}$ \\
\hline Politics andeconomics & 20 & 22,510 & $11^{\mathrm{o}}$ & 0,403 & $21^{\circ} \stackrel{o}{2}$ \\
\hline $\begin{array}{l}\text { Political, judicial, and bureaucratic } \\
\text { recruitment }\end{array}$ & 19 & 23,087 & 09 응 & 0,500 & $15^{\circ}$ \\
\hline Classes and interest groups & 10 & 11,003 & $21^{\circ}$ & 0,375 & $23^{\circ}$ \\
\hline $\begin{array}{l}\text { Social movements, organizations, } \\
\text { and collective actors }\end{array}$ & 42 & 47,210 & $04^{\circ}$ & 0,401 & $22^{\circ}$ \\
\hline Public security & 19 & 22,790 & $10^{0}$ & 0,483 & $18^{0}$ \\
\hline Politics, law, and judicial power & 12 & 15,678 & $15^{\circ}$ & 0,599 & $10^{\circ}$ \\
\hline Religion and politics & 09 & 7,866 & 25 o & 0,129 & $26^{\circ}$ \\
\hline \multicolumn{6}{|c|}{ Theory, methods, and ideas } \\
\hline Democratic theory & 39 & 49,280 & $03^{\circ}$ & 0,553 & $12^{\circ}$ \\
\hline Modern theory & 13 & 16,809 & $14^{\circ}$ & 0,585 & $11^{\circ}$ \\
\hline Contemporary theory & 29 & 35,101 & $06^{\circ}$ & 0,495 & $17^{\circ}$ \\
\hline History of ideas & 14 & 14,799 & $17 \underline{0}$ & 0,328 & $24^{\circ}$ \\
\hline Methodology & 11 & 15,576 & $16^{\circ}$ & 0,718 & $03^{\circ}$ \\
\hline Brazilian Political Thinking & 12 & 13,840 & $18^{\circ}$ & 0,433 & $20^{\circ}$ \\
\hline
\end{tabular}

Sources: Scielo and Scopus.

The following areas were excluded due to small N: Specific Governmental Institutions (01 case); Revolutions and Civil Conflicts (03 cases); Teaching and Research on PC and IR (01 case). There was one non-classifiable case. The relative value was standardized.

The areas of 'Political Institutions' represent $21.8 \%$ of the gross value, 'Political Behavior' represents 15.1\%, 'State and Civil Society' represents 18.7\%, and 'Theory, Methods, and Ideas' 13. 8\%. In relative terms, the most valuable areas are those of political institutions. Alongside 'Methodology', 'Executive-Legislative Relations' and 'Analysis of the Decision-Making Process' are the only very high yield areas. 
The case of 'Government, Bureaucracy, and Public Policy' must be highlighted. Although it often deals with institutions, it is eminently statal, also mobilizing more variables of hybrid nature (political-societal). In this sense, 'Methodology' is notable for being the third most valuable area and having strong ties to the institutional areas and a 'positivistic' stance. This is expressed by its politicism, its high score on scientificity and strong nomothetic orientation (LEITE, 2015, pp. 69, 204, 224 and 230).

At the same time, it is notable that if we exclude 'Government, Bureaucracy and Public Policy', retaining the most political areas of political institutions, there is a relatively restricted volume of gross value. One explanation is the still restrictive conditions of access of these areas, particularly when combined with the Rational Choice Institutionalism, favoring statistics based on the general linear model. It is a restricted and highly valuable fraction.

The areas of political behavior add a great deal of gross value and high levels of relative value. Here, the association with institutional politics remains, since these areas favor studies of elections and institutionalized forms of political participation (idem). Proximity to institutional politics tends to add academic value.

Academic capital falls as we move towards the more societal and theoretical areas. Nevertheless, the areas of 'State and Society' together represent $18.7 \%$ of the gross value and the three theoretical areas plus 'Brazilian Political Thought' represent 13.7\%. In other words, by volume, this portion of the field, the majority, represents a significant amount of capital, although it is worth little. 'Politics, Law and Judiciary' is the most valued of the societal and state areas, and some of its value is independent of its disciplinary tradition, referring to the importance attributed to its particular objects. This may indicate closeness between law and political science.

The average yield of the theoretical areas indicates that democracy and the classics, the nature of power and its relation with political regimes, are relatively valued in the field. The valuation of democracy as an object of study is echoed in institutionalist areas, which focus institutional politics under democratic regimes. The Democratic Theory also represents the third largest volume of capital, spanning an extensive economy with appreciable per capita values.

The microcosms of the field, which define alternative oppositions, are also not valued highly, occupying the lowest positions: 'Politics and Economics' (0.403 and 21 st place); 'Religion and Politics' (0.129 and 26th place) and 'History of Ideas' (0.328 and $24^{\text {th }}$ place). In other words, distance from the mainstream also implies less academic value.

\section{Nominal approaches}

The nominal approaches are broken down as follows (Table 05): 
Table 05. Ranking of Nominal Approaches

\begin{tabular}{|c|c|c|c|c|c|}
\hline Nominal approach & $\mathrm{N}$ & $V_{g}$ & Position & $\mathrm{V}_{\mathrm{r}}$ & Position \\
\hline \multicolumn{6}{|c|}{ Political science } \\
\hline Neoinstitutionalism & 67 & 78,684 & $01^{\circ}$ & 0,456 & $18^{\circ}$ \\
\hline Rational choice institutionalism & 37 & 48,995 & $02^{\circ}$ & 0,619 & $07^{\circ}$ \\
\hline Historical institutionalism & 18 & 20,251 & $10^{\circ}$ & 0,402 & $21^{\mathrm{o}}$ \\
\hline Political culture & 21 & 29,539 & $07^{\circ} \stackrel{0}{2}$ & 0,708 & $02^{\circ}$ \\
\hline Behavioralism & 10 & 15,388 & $13^{\circ}$ & 0,852 & $01^{\text {o }}$ \\
\hline Network analysis & 08 & 7,952 & $29^{\circ}$ & 0,260 & $34^{\circ}$ \\
\hline Elite analysis & 23 & 29,667 & $06^{0}$ & 0,581 & 09 은 \\
\hline Jurisprudence & 07 & 9,018 & $26^{\circ}$ & 0,580 & $10^{\circ}$ \\
\hline Politological empirismo & 27 & 35,931 & $03^{\circ}$ & 0,626 & $06^{\circ}$ \\
\hline Informational & 11 & 15,274 & $14^{\circ}$ & 0,689 & $04^{\circ}$ \\
\hline Feminism & 27 & 30,348 & $05^{\circ}$ & 0,401 & $22^{\circ}$ \\
\hline Liberal political theory & 06 & 8,064 & $28^{\circ}$ & 0,640 & $05^{\circ}$ \\
\hline Deliberationism & 12 & 14,827 & $15^{\circ}$ & 0,522 & $15^{\circ}$ \\
\hline Participativism & 14 & 15,929 & $12^{\circ}$ & 0,416 & $20^{\circ}$ \\
\hline Maquiavelian & 09 & 11,34 & $20^{\circ}$ & 0,549 & $13^{\mathrm{o}}$ \\
\hline Contratualism & 04 & 4,154 & $36^{\circ}$ & 0,308 & 290 \\
\hline Multiculturalism & 07 & 9,842 & $22^{\circ}$ & 0,708 & $03^{\circ}$ \\
\hline \multicolumn{6}{|c|}{ Political sociology } \\
\hline Marxism & 24 & 28,156 & $08^{\circ}$ & 0,455 & 19 o \\
\hline Theory of organizations & 29 & 34,492 & $04^{\circ}$ & 0,472 & $17^{\circ}$ \\
\hline Social actors & 10 & 9,674 & $23^{\circ}$ & 0,231 & $35^{\circ}$ \\
\hline Praxiological & 22 & 28,054 & $09^{\circ}$ & 0,565 & $12^{\circ}$ \\
\hline Interationism & 06 & 7,915 & $30^{\circ}$ & 0,613 & $08^{\circ}$ \\
\hline Etnometodological & 13 & 13,519 & $18^{\circ}$ & 0,310 & $28^{\circ}$ \\
\hline Critical theory & 06 & 6,085 & $32^{\circ}$ & 0,282 & $32^{\circ}$ \\
\hline Memory and political imaginary & 07 & 7,849 & $31^{\circ}$ & 0,398 & $23^{\circ}$ \\
\hline \multicolumn{6}{|c|}{ Historical sociology } \\
\hline Ideal types & 09 & 9,094 & $25^{\circ}$ & 0,278 & $33^{\circ}$ \\
\hline Structuralism & 04 & 5,032 & $34^{\circ}$ & 0,547 & $14^{\circ}$ \\
\hline Historiografical & 10 & 9,41 & 24 은 & 0,202 & $36^{\circ}$ \\
\hline Historical-interpretative & 18 & 19,578 & $11^{\circ}$ & 0,362 & $25^{\circ}$ \\
\hline \multicolumn{6}{|c|}{ Political economy } \\
\hline Economic institucionalism & 04 & 4,291 & $35^{\circ}$ & 0,345 & $26^{\circ}$ \\
\hline (Neo)developmentalism & 14 & 14,561 & $16^{\circ}$ & 0,310 & $27^{\circ}$ \\
\hline \multicolumn{6}{|c|}{ Linguistic-interpretative } \\
\hline Hermeneutical & 05 & 5,592 & $33^{\circ}$ & 0,395 & $24^{\circ}$ \\
\hline Linguistic contextualism & 09 & 11,586 & 190 & 0,579 & $11^{\circ}$ \\
\hline History of concepts & 07 & 8,446 & $27^{\circ}$ & 0,491 & $16^{\circ}$ \\
\hline Content analysis & 11 & 11,216 & $21^{\circ}$ & 0,288 & $31^{\circ}$ \\
\hline Post-modernist & 14 & 14,492 & $17^{\circ}$ & 0,305 & $30^{\circ}$ \\
\hline
\end{tabular}

Sources: Scielo and Scopus

Note: The following approaches were excluded due to small N: Rational Choice (03 cases); Systemic (02 cases); Pluralism (03 cases); Theories of Accountability (02 cases); Interest Group Theory (02 cases); Pragmatism (02 cases); Modernization Theory (02 cases); Dependence Theory (01 case); Semiologic (01 case) and Constitucionalism (03 cases). Fifteen non-classifiable cases. Relative value standardized. 
Institutionalist and attitudinal approaches are the most important. The institutionalist approaches predominate, representing the highest amount of capital while the attitudinal approaches (Behaviorism, Political Culture, and Informational) are the most valuable. Regarding the latter, the performance of Opinião Pública is key - today the most valued journal, which, in relation to 2004-2008, when it was A2, implied a higher valuation of the approaches and areas related to political attitudes and behavior.

The rise of Opinião Pública decreased the prominence of the institutionalist approaches, with a polarization in the elite ${ }^{16}$. However, in addition to predominating, institutionalist approaches are disseminated and less dependent on one periodical particularly its neo-institutionalism version ${ }^{17}$. In this case, its greatest extension involves an internal differentiation, which explains its lower relative value compared to the top tier: there is a neo-institutionalism that focuses on institutional politics, predominating in the most valued journals, especially in Brazilian Political Science Review. This fraction is equivalent, in relative value, to the Rational Choice Institutionalism. On the other hand, there is a fraction that focus on state organizations, applied in studies on bureaucracy and public policy, supported by Cadernos de Pesquisa and Ciência e Saúde Coletiva. Journals of interdisciplinary nature, they were never considered in studies on political science. In other words, the politological fraction of neo-institutionalism, closer to political science, is as valuable as the Rational Choice Institutionalism. Also, it is no coincidence that the latter predominates in the journals more identified with political science, such as the Brazilian Political Science Review. Political Empiricism, which submits self-evident political data to statistical tests, also composes the elite of the field and expresses the value that is assimilated by combining neo-positivism and institutional politics.

In relative terms, cases worthy of note are Multiculturalism (relative value of 0.708 , the $3^{\text {rd }}$ highest), Liberal Political Theory $\left(0.640,5^{\text {th }}\right)$, Interactionism $\left(.613,8^{\text {th }}\right)$ and Linguistic Contextualism $\left(0.579,11^{\text {th }}\right)$. However, this must be pondered by the restricted

16 Oliveira and Nicolau (2014, p. 13) also documented the growth of 'behavioralism' in recent years, taking the historically most important journals as the reference.

$17 \mathrm{Neo}$-institutionalism focuses on the functioning of political institutions without dealing with or considering the rational action of the actors. It is, therefore, a more structural approach than the rational choice variant. It is based on the classic paper by March and Olsen (2008), called 'normative neo-institutionalism' by Peters $(1999,2000)$. This added up to a more formalistic neo-institutionalism, based on the analysis of statutes and formal rules, as outlined by Amenta and Ramsey (2010). Both are contemplated by the 'neo-institutionalism' category here employed. 
number of cases, with the first three supported by two cases in A1 journals and one case in A2. Linguistic Contextualism is applied to linguistic-ideal objects (alongside Conceptual History and Hermeneutics), being the most important approach of this nature today.

On the other hand, the case of Feminism must be emphasized, for it represents a significant amount of gross capital (3.2\% of the total, $\left.5^{\text {th }}\right)$ associated with a low yield $\left(0.401,22^{\text {nd }}\right)$. We have an interesting peculiarity here. Feminism has an exclusive journal, Estudos Feministas, which alone supports 50\% of the approach, a percentage exceeded only by (Neo)Developmentalism, supported by the Revista de Economia Política (60\%). However, Feminism is far more extensive ( $4.8 \%$ compared to $2.5 \%$ of the production), is scarce in A1 and A2 journals, and is part of the main structure of the field, that is, the political-societal opposition, located at the societal extreme. Thus, on the one hand, Feminism was incorporated by political science, on the other, it is relatively undervalued within it.

We find a parallel in Marxism, which suffered a sharp decline compared to 2004-2008 (LEITE, 2010, p. 58), something striking for an approach that dominated political studies until the 1980s. In this sense, the absence of Crítica Marxista (B2) between the journals of the 'qualified production' is noteworthy. For its own sake, it must be noted that, contrary to Feminism, Marxism is more diffuse and less dependent on one journal.

In our opinion, the proximity of Feminism to the discussions on democratic theory is decisive. The intellectual and political distance in relation to less radical forms of democracy weighs against Marxism, making room for the growth of Multiculturalism, Feminism and studies on collective action among the intellectually unorthodox and normatively 'critical' approaches. Despite this, Marxism still has a higher yield $(0.455$, $19^{\text {th }}$, being more published in traditional journals such as the Revista de Sociologia $e$ Política and Lua Nova - that is, because of its historical importance.

Another case of significant concentration of gross capital associated with a low yield is the Theory of Organizations: it has the fourth highest gross value with a relative capital of $0.472,17^{\text {th }}$ place in the production. In our view, this is explained by competition with Neo-Institutionalism, favored by the pre-eminence of the political traditions in the field. 
The most important approach of political sociology is the praxeological approach $\left(2.9 \%\right.$ of the gross value, $8^{\text {th }}$, with a yield of 0.565 , median, $13^{\text {th }}$ in production), based on Pierre Bourdieu's studies on the political field. In practice, though, it oscillates between ignoring institutional politics (it is $50 \%$ societal) and treating it as dependent on societal factors (it is $22.7 \%$ societalist) (LEITE, 2015, p. 206).

In short, approaches closer to institutional politics, that mobilize politological factors in their arguments and that are more scientifically orthodox are favored by the current means of stratification.

\section{Disciplinary traditions}

Incorporated into journals, areas, and approaches, the disciplinary traditions were broken down as independent categories. Their hierarchy is identified in Table 06, below:

Table 06. Ranking of disciplinary traditions

\begin{tabular}{|c|c|c|c|c|c|}
\hline Disciplinary Tradition & $\mathrm{N}$ & $V_{g}$ & Position & $\mathrm{V}_{\mathrm{r}}$ & Position \\
\hline Politicist & 44 & 57,202 & $04 \stackrel{0}{\circ}$ & 0,592 & $02^{\circ}$ \\
\hline Politological & 116 & 148,642 & $02^{\circ} \underline{0}$ & 0,572 & $03^{\circ}$ \\
\hline Polit. intermediary & 21 & 30,917 & $08^{\circ}$ & 0,780 & $01^{\circ} \underline{\mathrm{o}}$ \\
\hline State & 46 & 51,172 & $05^{\circ}$ & 0,389 & 09 은 \\
\hline Statist & 69 & 77,931 & $03^{\circ} \stackrel{-}{-}$ & 0,407 & $08^{o}$ \\
\hline Societal & 172 & 202,083 & $01^{\underline{o}}$ & 0,456 & $05^{\underline{o}}$ \\
\hline Societalist & 37 & 43,308 & $06^{\circ}$ & 0,452 & $06^{\circ}$ \\
\hline Economic & 12 & 13,259 & $10^{\circ}$ & 0,380 & $10^{\circ}$ \\
\hline Economicist & 15 & 17,091 & 09 은 & 0,418 & $04^{\circ} \underline{\mathrm{o}}$ \\
\hline Idealist & 35 & 39,386 & $07^{\circ} \stackrel{0}{ }$ & 0,403 & $07^{\circ}$ \\
\hline
\end{tabular}

Source: Scielo and Scopus

The division between the politological and other traditions is found in journals, areas, approaches and other properties of the production. This division is also reproduced in the hierarchy between traditions. Together, the politological tradition represent the highest amount of gross value. The intermediary tradition stands out due to its high yield. Based on institutionalized links between societal actors and institutional politics, it manifests the importance of the association between attitudinal studies and democracy in Brazilian political science - and probably elsewhere, particularly the United States.

The highest concentration of capital is among the politological and societal traditions, with $50.7 \%$ of the academic capital measured and the greatest yields per 
capita. Most of the field is structured according to this opposition and competes for the resources at stake in this region.

Both the societal traditions are interesting cases. Both have the same yield, despite a fundamental difference: the object of societalism is institutional politics, treated as an order dependent on societal factors. In one case, institutional politics is ignored. On the other, it is heteronomous. In both ways, value is lost. But we face another interesting aspect. Societalism has higher values of scientificity. Scientificity in 'positivistic' lens are big aggregators of value, as we will see in the next sections. Thus, while it gains value on one hand, it loses on the other by treating institutional politics as a heteronomous order.

In short, the following factors are involved in determining the value: 1) distance from institutional politics: addressing it adds value; 2) approach to institutional politics: addressing it as a heteronomous order subtracts value.

The economic and idealist traditions constitute distant microcosms of the central structure of the field, composed of the oppositions between statal, societal and politological traditions. At the same time, the strongest oppositions are from the categories furthest from the mainstream (LEITE, 2015, p. 206 et seq.). The data shows that the most distant regions are also less valuable. The oppositions get stronger as the yield gets lower.

An interesting corollary to prove this is the increase in chances of academic success in proportion to a greater relative value, not only favoring intellectual prestige, but also increasing the chances of occupying higher academic positions ${ }^{18}$. In this sense, the current hierarchy expresses and reinforces the establishment of political traditions as defining characteristics of political science as an autonomous discipline. It started with the foundation of graduate programs at UFMG (1967) and Iuperj (1969), and was expanded and strengthened by programs at UFRGS (1973), USP (1974) and UFPE (1982), with Unicamp (1984) being one of the first to take an unorthodox position, societal especially, in the institutionally autonomous field of political science ${ }^{19}$. Today,

18 One way to prove it would be to analyze the production and academic trajectory of the occupants of the key academic positions in the field, such as area coordinators, directors of associations, and coordinators of graduate programs, using a regression model with the relative value as a predictor and the occupation of these positions as the resultant.

${ }_{19}$ For further details, cf. Leite (2015, pp. 119-131), Keinert and Silva (2010), Forjaz (1997), Lamounier (1982), Trindade (2007), Veiga (1987), among others. 
all programs classified as 06 and 07 by CAPES, the higher tier, could be considered fundamentally politological.

However, there is no great disparity between politological from societal. It would be necessary to use 'high-medium' and 'low-medium' substratum to distinguish them, which may not be significant. This indicates that there is no great inequality in the field with regard to these traditions alone. The categories, however, act together, deepening stratification when we insert intellectual traditions, especially measures of scientificity.

\section{Intellectual traditions}

\section{Breadth and scope of the argument}

First, we checked whether there is a difference between the academic capital of structural and subjectivist arguments, a classic opposition of the social sciences, or between nomothetic and idiographic arguments, a classic opposition of humanities.

Table 07. Ranking of breadth and scope of the argument

\begin{tabular}{lccccccc}
\multicolumn{1}{c}{ Breadth } & $\mathrm{N}$ & $\mathrm{V}_{\mathrm{g}}$ & $\mathrm{V}_{\mathrm{r}}$ & Scope & $\mathrm{N}$ & $\mathrm{V}_{\mathrm{g}}$ & $\mathrm{V}_{\mathrm{r}}$ \\
\hline $\begin{array}{l}\text { + Structure } \\
\text { (objectivism) }\end{array}$ & 314 & 377,358 & 1,202 & + Nomothetic & 230 & 299,957 & 1,304 \\
+ + Agency & & & & & & & \\
(subjectivism) & 248 & 297,229 & 1,198 & + Ideographic & 332 & 374,665 & 1,128 \\
\hline
\end{tabular}

The average yield of studies closer to structure and studies closer to the agency is identical. Studies from each tradition are distributed homogeneously in approaches and perspectives of high and low value. Elsewhere, it was also shown that although more structural studies predominate among A1 and A2 journals, there is no association between more structural or more subjectivist arguments and the Qualis ratio of the journals: both are distributed more or less homogeneously among the strata.

Contrary to the breadth, for the scope there is a clear difference in yields, nomothetic valuing more. To assimilate more capital, idiographic studies need to be associated with high-yield approaches and areas, such as behavioralism or idiographic studies of institutional arrangements. It should be noted, however, that the greater the 
level of disparity in relative value between the categories, the lower the compatibility between them ${ }^{20}$.

\section{Nature of the object and scientific measurements}

The scientific measurements show that a more orthodox conception of science is currently more valued: the more 'scientific' attributes are assimilated, the higher the value. We started by differentiating the nature of the object of the studies (Table 08) and then specifying them according to the nature of evidence.

Table 08. Scientific measures

\begin{tabular}{lccclccc}
\hline Subject Nature & $\mathrm{N}$ & $\mathrm{V}_{\mathrm{g}}$ & $\mathrm{V}_{\mathrm{r}}$ & Evidences* & $\mathrm{N}$ & $\mathrm{V}_{\mathrm{g}}$ & $\mathrm{V}_{\mathrm{r}}$ \\
\hline Empirical & 418 & 493,708 & 0,463 & Quanti & 123 & 164,011 & 0,629 \\
Theoretical & 128 & 144,215 & 0,404 & Hybrid & 97 & 119,209 & 0,515 \\
Linguistic-ideal & 21 & 22,823 & 0,466 & Quali & 186 & 201,060 & 0,354 \\
& & & & Bibliograp & 156 & 173,299 & 0,387 \\
\hline
\end{tabular}

Note: $\left(^{*}\right)$ Five cases not showing evidence were not computed.

Empirical objects command nearly $70 \%$ of gross value, but they settled in a way that 'being empirical' alone does not guarantee greater value - it is necessary, in general, to address these objects through quantitative evidence ${ }^{21}$. Note that since empirical objects may be studied with quantitative, qualitative or hybrid evidence, their relative value is an average of the relative values of these kinds of evidence. Considering the relative value of the theoretical and linguistic-ideal objects, we can even deduce that individual empirical studies may be penalized if they do not gather quantitative evidence. Empirical objects lose value when associated with qualitative or bibliographic evidence, and gain value when associated with quantitative or hybrid evidence. Thus, the distribution of relative value follows these parameters, from highest to lowest yield: 1) empirical and quantitative; 2) theoretical and bibliographical (theoretical essays); 3) empirical and qualitative; 4) empirical and bibliographical (empirical essays).

${ }^{20}$ In this sense, measures of association can help to uncover these associations and identify niches. For further details, cf. Leite (2015:, p. 231 et seq.).

${ }^{21}$ In correspondence analysis, Leite (2015, pp. 35-36) shows that empirical objects, which comprise $73.7 \%$ of the production, command the majority of the inertia of the field, defining its mainstream, while theoretical objects, with $22.6 \%$, constitute a nucleus that is opposed to the center. 
We also note that since qualitative evidence covers a greater margin of gross value, we have an elite in the field, in form of empirical-quantitative studies. This distribution suggests a hierarchy between three intellectual traditions, from the most to the less valued: science, philosophy and literature. In other words, a humanistic conception of knowledge, closer to philosophy and literature, is presently undervalued in the field of production, in favor of a more scientific or 'positivistic' stance.

This becomes clearer when we consider strict measures of scientificity such as use of statistics, presentation of hypotheses and causality (Table 09):

Table 09. Orthodox scientificity measures

\begin{tabular}{ccccc}
\hline Statistics & $\mathrm{N}$ & $\mathrm{V}_{\mathrm{g}}$ & $\mathrm{V}_{\mathrm{r}}$ \\
\hline Bivariate & & 15 & 22,638 & 1,509 \\
GLM & & 74 & 102,430 & 1,384 \\
Univariate & 13 & 15,099 & 1,161 \\
Simple Frequency & & 116 & 139,847 & 1,206 \\
Do not use & & 349 & & 1,097 \\
& & & & \\
Hipothesis & Yes & 213 & 266,631 & 1,252 \\
& No & 354 & 396,148 & 1,119 \\
Causality & & & & \\
& Yes & 287 & 351,875 & 1,226 \\
& No & 280 & 310,904 & 1,110 \\
\hline
\end{tabular}

Orthodox or 'positivistic' studies are more valued in the field. The studies that employ statistics have a much greater yield than studies without statistics and that yield increases with the degree of complexity. Bivariate statistics and GLM compose an elite in the field, still relatively restricted and highly valuable. This should set a benchmark from which political science will aim to evaluate itself, especially as it becomes more mathematical. Presentation of hypotheses and causal arguments are also appreciated.

It is important to remark that the categories of higher yield still do not hold the greatest gross value, with the exception of causality. In this sense, taken diachronically, there is likely to be a movement toward expansion of the more orthodox view, particularly since the $2000 \mathrm{~s}^{22}$.

In short, the more orthodox conception of science - eristic, empirical, quantitative, statistical, hypothetical and causal - is the most valued in the field, reflecting the success of the political science implemented in the late 1960s and the

${ }^{22}$ Using slightly different categories, the findings of Oliveira and Nicolau (2014) support this hypothesis.

(2016) $10(1) \quad$ - e0006-24/29 
early 1970s. Despite this, most members of the field of political science do not adhere to this conception. In this sense, the greater appreciation of the more orthodox categories may attract more authors, also gradually increasing the volume of this tradition.

\section{Conclusions}

The structure of the distribution of value depends on the combination of the values associated with the effective properties in the structuring of a given field of production. In particular, two sets of properties are effective: disciplinary traditions and intellectual traditions (LEITE, 2015).

This article demonstrates that societalism, humanistic, qualitative, absence of hypothesis, absence of causality, and idiographic orientation constitute the most peripheral portion of the academic production of political science in Brazil. Instead, polititological, quantitative, sophisticated statistics, hypotheses, causality, and nomothetic orientation is the most valuable combination. In the elite, there is a more orthodox political science, that is, politological and scientific. Besides, there is a more unorthodox political science, a political science in broad sense, a science of power, inequality, forms of domination, and of humanistic features.

It is noteworthy that appreciation of institutional politics also signifies appreciation of democracy: in practice, we generally study political institutions under democratic rule - or with democratic regimes or values in mind, like Comparative Politics in the United States or the studies on Brazilian authoritarian institutions of the first generation of Brazilian political scientists, back in the 1960s.

In fact, these combinations may be found in areas, and above all, in nominal approaches. In the Brazilian political science most valued nucleus, there is the Rational Choice Institutionalism and Political Culture, and areas of political behavior and political institutions. In the least valued nucleus, we have approaches such as Historiography and Critical Theory, and historical, societal and theoretical areas. In other words, the properties of highest value are related to each other. The same applies to the least valued ones. The compatibility then follow the association between the categories. Thus, properties with opposite values tend to be less compatible.

What does this mean for the structuring of the field of production? We showed elsewhere that the most highly valued properties also constitute the factors of greatest inertia in the dimensions of the production (LEITE, 2015, pp. 45-58, 59-87). That is, 
they act as principles of division: more scientific or more politicological studies are more valued because the opposition between disciplinary and intellectual traditions are structuring the field and determining the distribution of value.

And how they achieve this? They act symbiotically with stratification mechanisms. Thus, the distribution of value expresses the success of certain groups of political scientists, and the institutions associated with them, in the formation of the hierarchy of the academic production. This determination occurs on two levels. First, the intellectual content of the production is determined. Second, the value assigned to that content is determined using the most effective stratification mechanisms, from more to less institutionalized: Qualis, the impact factor, and identification with political science.

We could then rightfully ask about the possible implications on the career of a researcher. It can be deduced that the more valued properties are incorporated to the study, the higher the chances of publication in the most valued journals. Additionally, it may increase the chances of occupying positions of prestige in the field. In this case, it is necessary to analyze the relationships between the distribution of capital identified herein and the distribution of other forms of academic capital, such as positions held in professional associations and committees and prestigious institutional ties. Thus, the more valued the intellectual attributes, more academic capital and more chances of professional success. On the contrary, less valued attributes may hinder professional trajectory and contribute to less prestigious positioning. This may impel rejection and initiative to modify the parameters of the existing stratification mechanisms, or their complete subvention ${ }^{23}$.

At last, since the stratification mechanisms are so important to the economy of the field, could the hierarchy of the discipline be linked to the vigorous expansion of Brazilian political science since the 2000s? We believe that the stratification mechanisms contribute to the expansion of the discipline as factors of a wider process of 'autonomization' in relation to other social sciences. We believe that this process accelerated from the 2000 s due to the strengthening of the politological-scientific tradition, which focuses institutional politics and mobilizes more orthodox scientific approaches. The problem is how it will deal with the other traditions: will they become a part of political science or will they be shifted to sociology and other disciplines? In this

${ }^{23}$ Cf. for example, the declaration of Miguel (2015) criticizing the demands of the Scielo and the orientation of current political science in Brazil.

(2016) 10 (1) = $\mathrm{e} 0006-26 / 29$ 
vein, the future of the discipline ultimately depends on its stratification mechanisms. There is, therefore, an important array of issues still to be investigated in the studies about political science.

Translated by ViaMundi

Submitted in March 2015

Accepted in September 2015

\section{References}

ABCP (2012), Thematic areas. Available at <http://www.cienciapolitica.org.br/encontros/8o-encontro-abcp/areastematicas/> Accessed on May 30, 2013.

ALMEIDA, Maria Herminia Brandão Tavares (2001), Dilemas da institucionalização das Ciências Sociais no Rio de Janeiro. In: História das Ciências Sociais no Brasil. Edited by MICELI, S.Vol. 01. São Paulo: Sumaré. pp. 223-255.

AMENTA, Edwin and RAMSEY, Kelley M. (2010), Institutional theory. In: Handbook of politics: state and society in global perspective. Edited by LEICHT, K.T. and JENKINS, J.C.. New York: Springer. pp. 15-40.

ARRUDA, Maria Arminda do Nascimento (2001), A modernidade possível: cientistas e ciências sociais em Minas Gerais. In: História das Ciências Sociais no Brasil. Edited by MICELI, Sergio. Vol. 01. São Paulo: Sumaré. pp. 277-368.

BOURDIEU, Pierre (1984), Distinction: a social critique of the judgment of taste. Cambridge, MA: Harvard University Press. 640 pp.

BURKE, Peter (2000), A social history of knowledge: from Gutenberg to Diderot. Cambridge, UK: Polity Press. 268 pp.

CAPES (2013), Documento de Área de 2013. Avaliação trienal 2013. Ciência Política e Relações Internacionais. Brasília. 50 pp.

CAPES (2012), Areas of Expertise Table. Available at <http://www.capes.gov.br/avaliacao/instrumentos-de-apoio/tabela-de-areas-doconhecimento-avaliacao> Accessed on May 30, 2014.

KAPLAN, Abraham (1964), The conduct of inquiry: methodology for behavioral science. San Francisco: Chandler. 428 pp.

KEINERT, Fábio Cardoso and SILVA, Dimitri Pinheiro (2010), A gênese da ciência política brasileira. Tempo Social. Vol. 22, № 01, pp. 79-98. 
LAMOUNIER, Bolivar (1982), A ciência política no Brasil: roteiro para um balanço crítico. In: A Ciência Política nos anos 80. Edited by LAMOUNIER, Bolivar. Brasília: Editora UnB. pp. 407-433.

FORJAZ, Maria Cecília Spina (1997), A emergência da ciência política no Brasil: aspectos institucionais. Revista Brasileira de Ciências Sociais. Vol. 12, № 35.

LEITE, Fernando (2015), O campo de produção da ciência política brasileira contemporânea: uma análise histórico-estrutural de seus princípios de divisão a partir de periódicos, áreas e abordagens. PhD Dissertation in Sociology. Curitiba: Universidade Federal do Paraná.

LEITE, Fernando (2010), Divisões temáticas e teórico-metodológicas na ciência política brasileira: explicando sua produção acadêmica (2004-2008). Masters' dissertation in Sociology. Curitiba: Universidade Federal do Paraná.

LEITE, Fernando and CODATO, Adriano (2013), Autonomização e institucionalização da ciência política brasileira: o papel do sistema Qualis-Capes. Revista de Discentes de Ciência Política da UFSCAR. Vol. 01, № 01, pp. 01-21.

LESSA, Renato (2010), 0 campo da ciência política no Brasil: uma aproximação construtivista. In: Horizontes das ciências sociais no Brasil: ciência política. Edited by MARTINS, Carlos Benedito and LESSA, Renato. São Paulo: Anpocs. pp.13-50.

LESSA, Renato (2011), Da interpretação à ciência: por uma história filosófica do conhecimento político no Brasil. Lua Nova. № 82, pp. 17-60.

MARCH, James G. AND OLSEN, Johan P. (2008), Neo-institucionalismo: fatores organizacionais da vida política. Revista de Sociologia e Política. Vol. 16, № 31, pp. 121-141.

MARENCO, André (2015), The three Achilles' heels of Brazilian political science. Brazilian Political Science Review. Vol. 08, № 03, pp. 03-38.

MARTINS, Carlos Benedito and LESSA, Renato (2010), Horizontes das Ciências Sociais no Brasil: ciência política. Edited by MARTINS, Carlos Benedito and LESSA, Renato. São Paulo: Anpocs. 402 pp.

MICELI, Sergio (1993), A aposta numa comunidade científica emergente. A Fundação Ford e os cientistas sociais no Brasil (1962-1992). In: A Fundação Ford no Brasil. Edited by MICELI, Sergio. São Paulo: Editora Sumaré. pp. 33-98.

MICELI, Sergio (1990), A desilusão americana: relações acadêmicas entre Brasil e Estados Unidos. São Paulo: Sumaré. 80pp.

MIGUEL, Luis Felipe (2015), Qual é a do Scielo? Painel Acadêmico. Jan 08. 
OLIVEIRA, Lilian and NICOLAU, Jairo (2014), A produção da ciência política brasileira: uma análise dos artigos acadêmicos (1966-2013). Anais Eletrônicos do IX Encontro da Associação Brasileira de Ciência Política. Brasília. Aug 04-07.

PEIXOTO, Fernanda Arêas (2001), Franceses e norte-americanos nas ciências sociais brasileiras (1930-1960). In: História das ciências sociais no Brasil. Edited by MICELI, Sergio. Vol. 01. São Paulo: Editora Sumaré. pp.477-532.

PETERS, Guy (1999), Institutional theory in political science: the 'new institutionalism'. London/New York: Continuum. 232 pp.

PETERS, Guy (2000), Institutional theory: problems and prospects. Reihe Politikwissenschaft. Vol. 69, pp. 01-15.

QUIRINO, Célia (1994), Departamento de ciência política. Estudos Avançados. Vol. 08, № 32, pp. 337-348.

REIS, Fábio Wanderley (1997), As ciências sociais nos últimos 20 anos. Revista Brasileira de Ciências Sociais. Vol. 12, № 35.

ROCHA E SILVA, Mauricio (2009), O novo Qualis, que não tem nada a ver com a ciência do Brasil. Carta aberta ao presidente da Capes. Clinics. Vol. 64, № 08, pp. 721-724.

SETENARESKI, Ligia Eliana (2013), Repositórios digitais abertos: um movimento do livre acesso alternativo à estrutura oligopolizada das editoras científicas. Masters' dissertation in Public Policies. Curitiba: Universidade Federal do Paraná.

SOARES, Gláucio Ary Dillon (2005), 0 calcanhar metodológico da ciência política no Brasil. Sociologias, problemas e práticas. № 48, pp. 27-52.

THOMAZ, Petronio Generoso; ASSAD, Renato Samy and MOREIRA, Luiz Felipe P. (2011), Uso do fator de impacto e do índice $\mathrm{H}$ para avaliar pesquisadores e publicações. Arquivos Brasileiros de Cardiologia. Vol. 96, № 02, pp. 90-93.

TRINDADE, Hélgio (2007), Ciências sociais no Brasil em perspectiva: fundação, consolidação e expansão. In: As ciências sociais na América Latina em perspectiva comparada. Edited by TRINDADE, Hélgio. 2 ${ }^{\mathrm{a}}$ ed. Porto Alegre: Editora UFRGS. pp. 71-170.

TRINDADE, Hélgio (2012), Ciências Sociais no Brasil: diálogos com mestres e discípulos. São Paulo: Anpocs. 366 pp.

VEIGA, Luciana (1987), A trajetória de uma geração de cientistas sociais em Belo Horizonte: imagens de anos nem sempre dourados. Sociedade Brasileira de Sociologia. Paper delivered at $3^{\text {o }}$ Congresso Nacional de Sociologia. Brasília. 